\title{
Implementation of Clinical Supervision to Increase Work Commitment of Primary School Teachers
}

\section{Gusti Ayu Kusumawati}

UPT Kecamatan Blahbatuh Gianyar, Imdonesia

\author{
A RTICLEINFO \\ Article history: \\ Received 18 March 2020 \\ Received in revised form \\ 30 April 2020 \\ Accepted 5 May 2020 \\ Available online 15 May \\ 2020 \\ kata kunci: \\ komitmen kerja guru, \\ supervisi klinis. \\ keywords: \\ teacher work commitment, \\ clinical supervision.
}

\begin{abstract}
A B S T R A K
Kinerja guru Selama ini menjadi masalah yang tidak henti dibicarakan jika asil pembelajaran tidak menunjukkan hasil yang baik. Oleh sebab itu, penelitian ini adalah untuk meningkatkan komitmen kerja guru SD melalui kegiatan supervisi klinis. Penelitian ini adalah penelitian tindakan sekolah. Subjek penelitian adalah guru SD berjumlah 58 orang gurus. Data komitmen kerja guru pada penelitian ini dikumpulkan menggunakan kuesioner. Teknik analisis data menggunakan analisis deskriptif. Indikator keberhasilan penelitian ini adalah: apabila rata-rata komitmen kerja guru minimal pada kategori Tinggi, dan ketuntasan klasikal sebesar 90\%. Berdasarkan penelitian yang telah dilakukan, disimpulkan bahwa penerapan supervisi klinis secara efektif dapat meningkatkan komitmen kerja guru SD. Pada pra siklus rerata komitmen kerja guru adalah 128,74 berada pada kategori sedang dengan persentase ketuntasan klasikalnya adalah $67,24 \%$. Pada siklus I rerata komitmen kerja guru adalah 145,98 berada pada kategori tinggi dengan persentase ketuntasan klasikalnya adalah $87,93 \%$. Sedangkan pada siklus II meningkat dengan rerata sebesar
\end{abstract} 180,45 berada pada kategori sangat tinggi dengan persentase ketuntasan klasikalnya adalah $100 \%$. Supervisi Klinis berdampak positif pada peningkata komitmen kerja guru SD. Hasil penelitian ini dapat dijadikan salah satu instrumen dan bahan kajian dalam miningkatkan serta menjaga komitmen kerja guru SD.

\section{A B S T R A C T}

The purpose of this study was to determine the increase in elementary school teacher work commitments in Gugus 3 Kecamatan Blahbatuh Kabupaten Gianyar Semester II Academic Year 2018/2019 after attending clinical supervision activities. This research is a school action research. Subjects were elementary school teachers in Gugus 3 Kecamatan Blahbatuh Kabupaten Gianyar with a total of 58 teachers. Teacher work commitment data in this study were collected using a questionnaire. Data analysis techniques used descriptive analysis. Indicators of the success of this study are: if the minimum teacher work commitment is in the High category and classical completeness is $90 \%$. Based on the research that has been done, it was concluded that the effective implementation of clinical supervision could increase the work commitments of elementary school teachers in Cluster 3 of Blahbatuh District, Gianyar Regency Semester II in 2018/2019 Academic Year. In the pre-cycle mean teacher work commitment is 128.74 in the medium category with the percentage of classical completeness is $67.24 \%$. In the first cycle the mean work commitment of teachers was 145.98 in the high category with the percentage of classical completeness being $87.93 \%$. Whereas, in cycle II it increased with a mean of 180.45 in the very high category with the percentage of classical completeness being $100 \%$.

\section{Introduction}

Education is the most important aspect which cannot be separated from our life (Novrinda et al., 2017). Man and education are unseparable. Education can be defined as a plan to humanizing the human for the betterment (Wasitohadi, 2014). Education can be the indicator that determines someone's social strata. The higher his education, the more he will be respected in the society (Sahertian, 2000; Shaleh, 2016). Undang-undang Sisdiknas No. 20 Tahun 2003 states that education can embody the learning process which will make the students actively create and develop their spiritual, self-control, personality, intelligence, noble character, and creativity that will be needed not only by himself but also by the society and the nation (Sistem Pendidikan Nasional, 2003). According to the statement of UU No. 20 tahun 2003 about SISDIKNAS, a line can be drawn that the purpose of

\footnotetext{
1 Corresponding author. 
education is to embody a learning environment where the students can actively dig their potential. To reach the expectation, Indonesian education implementation is conducted based on the curriculum.

Education cannot be separated from teachers' roles (Susilo \& Sarkowi, 2018; Suwardi \& Farnisa, 2018). Teachers hold the most strategic role, especially in forming the nation noble characters and in developing the students' potential. Teachers have really important role in determining the success of education (Mukhtar, 2015; Sumarno, 2016). Professional teachers are expected to produce qualified graduates. Teachers' professionalism as the spearhead in curriculum implementation needs to be noticed (Depdiknas, 2005, 2007). In the teaching and learning process, teachers need to push, supervise, and facilitate the students in reaching their goals. The material delivery is the tiniest part of the dynamic steps in the students' development process (Kirom, 2017; Mukhtar, 2015).

An increased effectiveness at school is really determined by supervisors' performance. Wellperformed supervisors can be reflected in the management ability which is able to: (a) spel out the resources to provide an adequate support for the teachers, teching materials and well facilities maintenance; (b) give enough time to manage and coordinate the instructional process; (c) communicate regularly with the staffs, parents, and related community. In other words, school effectivity is determined by the supervisors' managerial leadership (Salim, 2017).

In education world, commitment and professionalism of the teachers are expected because teaching is the core of the education itself. As a profession, the job of teacher is not only exhausting physically and intellectually, but also expecting an effective pshycologycal state. Commitment has an important role in working, because it becomes the supporter to make them more responsible. However, the reality proves that most of organizations and companies are less concern on the employees' loyality, thus their performance is not optimal (Euis, 2015; Lailatussaadah, 2015; Naro, 2017).

The status quo in Gugus 3 Kecamatan Blahbatuh Kabupaten Gianyar Semester II Academic Year 2018/2019 shows that the teachers' performance tends to be low. This is reflected from teachers rarely use innovative learning in learning, some administering teachers still tend to be low, and there are some teachers who are shy in conveying the obstacles they face in carrying out the task. The impact of the problem makes the education process in Gugus 3 Kecamatan Blahbatuh Kabupaten Gianyar Semester II Academic Year 2018/2019 is less optimal.

To overcome the above problems, clinical supervision can be applied. Basically, supervision is really needed by the teachers, because they want victory in the implementation of their function and teaching assignment. Some of the importance of clinical supervision based on Ma'mur Asmani (2012); Hoy \& Horsyth (1986); Suharsini (2006) are such as. 1) there is no feedback from the competent people realated to profesional practice to fullfill the standard competency and etical code, 2) missed science and technology in the learning process ,3) loosing profesional identity, 4) profesional boredom, 5) acute violation of the code of ethics, 6) massively repeated mistakes, 7) Erosion of knowledge gained from pre-service education, 8) Students are disadvantaged, do not get the service they should, and 9) the low appreciation and trust of the public and trust providers. Clinical supervision is carried out to find out which aspects that make the teacher unable to teach well, then those aspects are examined one by one intensively and then find solutions to solve them, (Yulia Jayanti Tanama, Achmad Supriyanto, 2016).

Clinical supervision is a form of supervision implementation which is focused on the efforts to improve the learning process which is carried out by teachers through programmed (Nurcholiq, 2017). Thus, clinical supervision has big role in the process of teachers' performance evaluation. Clinical supervision is done to find teahcers' weaknesses in the implementation of learning process which is indirectly influence the teachers' performance (Andani et al., 2017). Clinical cupervision is different from the other type of supervision.

Clinical supervision is a supervision with essential characteristics, such as: (1) the supervisor guidance to the teachers is in form of help, not an order or instruction, so, the initiative and responsibility for self-development rests with the teacher; (2) interaction relationship in the supervision process is a collegial, so, it is intimate and open; (3) although the teaching performance of teachers in the classroom is broad and integrated, but the target of supervision is limited to what is contracted; (4) the target of supervision is submitted by the teacher, reviewed and agreed upon in the contract; (5) The clinical supervision process goes through three stages: preliminary meetings, classroom observations, and feedback meetings; (6) the observation instrument was determined jointly by the teacher and supervisor; (7) objective and specific feedback is given immediately; (8) analysis and interpretation of observational data are carried out together; (9) the cyclic supervision process (Amani et al., 2013). Many studies have been carried out relating to clinical supervision. 
The research was carried out by Yulia Jayanti et al. (2016) The results of the study showed that the implementation of clinical supervision was carried out in three stages, namely the planning phase, the implementation phase, and the feedback stage had been going well and could increase teacher professionalism. The first step is planning. The planning carried out in this study is related to initial discussions between the principal and the teacher who will carry out clinical supervision activities. The second stage is implementation. The implementation of clinical supervision at SDIT Bumi Darun Najah focuses on the third phase of learning activities, namely feedback. Feedback activities contain activities to convey the things recorded in the assessment instrument that has been prepared. Relevance to this research is the process carried out together using the stages of planning, implementation, and feedback. Research conducted by (Utami, 2017) which states that clinical supervision improves teacher performance in the learning process, this is evident from the increase in achievement per cycle shows an increase. Research results from (Astuti, 2017) Clinical Supervision is a guidance process aimed at assisting professional development of teachers / prospective teachers, especially in teaching performance based on observation and analysis of accurate and objective data as guidelines for changing teaching behavior. So, it can be said that clinical supervision has a positive impact on improving teacher performance.

Based on the explanation above, this research aimed at implementing clinical supervision to improve the work commitment of elementary school teachers in Gugus 3 Kecamatan Blahbatuh Kabupaten Gianyar Semester II Academic Year 2018/2019. The results of observations indicate the commitment of teachers at this school is still lacking. Hoping to find weaknesses or obstacles faced by teachers can help improve teacher performance.

\section{Method}

The present research is pseudo-experiement. The independent variable was the giving of Ludo in learning while the dependent variable was the collaboration skills of students who took the lessons. Purposive sampling was used with 21 students as the sample. The instrument of data collecting was students' collaboration creativity assessment form. The form was masured by 15 collaboration indicators by Greenstein (2012) namely: 1) Work productively with a group of friends; 2) Participate and contribute actively; 3 ) Balance in listening and speaking, being first and being a follower in the group; 4) Demonstrate flexibility and compromise; 5) Work colleagues with various types of people; 6 ) Respect other people's ideas; 7) Demonstrate the skill of taking a view or perspective; 8) Appreciate the contribution of each group member; 9) Matching tasks and work based on the strengths and abilities of individual group members; 10) Work with others to make decisions that include the views of several individuals; 11) Participate respectfully in discussions, debates, and differences of opinion; 12) Commit to prioritizing group goals; 13) Considering the interests and needs of the larger group; 14) Work together to solve problems and generate new ideas and products; 15) Responsible for joint work to complete. After the instrument was made, the next level was validity and reliability test whether the collaboration sheet can be used and can distinguish between students who have collaboration skills and not during the learning process. The data analysis that was carried out was an international analysis, which consisted of two tests, namely the prerequisite test and the hypothesis test. The prerequisite tests conducted are the normality test and the homogeneity test, where both of these tests aim to find out whether the research results are normal and homogeneous, which will later be used for the terms of the hypothesis test. To test the hypothesis used paired sample t-test with the provisions of the provisions of 1 ) reject Ho if the value of sig. (2-tailed) is smaller than the alpha value $(0.05)$, and 2) accept Ho if the value is sig. (2-tailed) is greater than the alpha value (0.05).

\section{Result and Discussion}

Based on the analysis of teacher work commitment data prior to the study, it was found that the average work commitment of teachers was 128.74 in the medium category, with classical completeness of $67.24 \%$. It is seen that there needs to be an improvement in efforts to increase teacher work commitments in cluster 3 of Blahbatuh District, Gianyar Regency Semester II, 2018/2019 Academic Year. Based on research that has been done by implementing clinical supervision, the results obtained in the first cycle the average work commitment of teachers is 145.98 and are in the high category. The percentage of classical completeness is $87.93 \%$. That is because 7 teachers get a busty score in the medium category. The constraints faced in the first cycle were that teachers were not optimal in implementing innovative learning in the classroom and there were some teachers who were less open about the problems they faced in carrying out their duties in school. 
To further maximize the results of research in cycle I, the second cycle research was conducted with attention to all obstacles that occurred in cycle I. In cycle II the teacher's work commitment increased, it can be seen from the average work commitment of teachers is 180.45 and is in the very high category. The percentage of classical completeness is $100 \%$. This shows that the constraints faced in Cycle I can already be overcome in Cycle II. Therefore the minimum completeness criteria are good and 100\% classical completeness has been fulfilled so that the research in cycle II was declared successful and the cycle was stopped.

The improved average and classical completeness in the results of this study can be illustrated in the following histogram

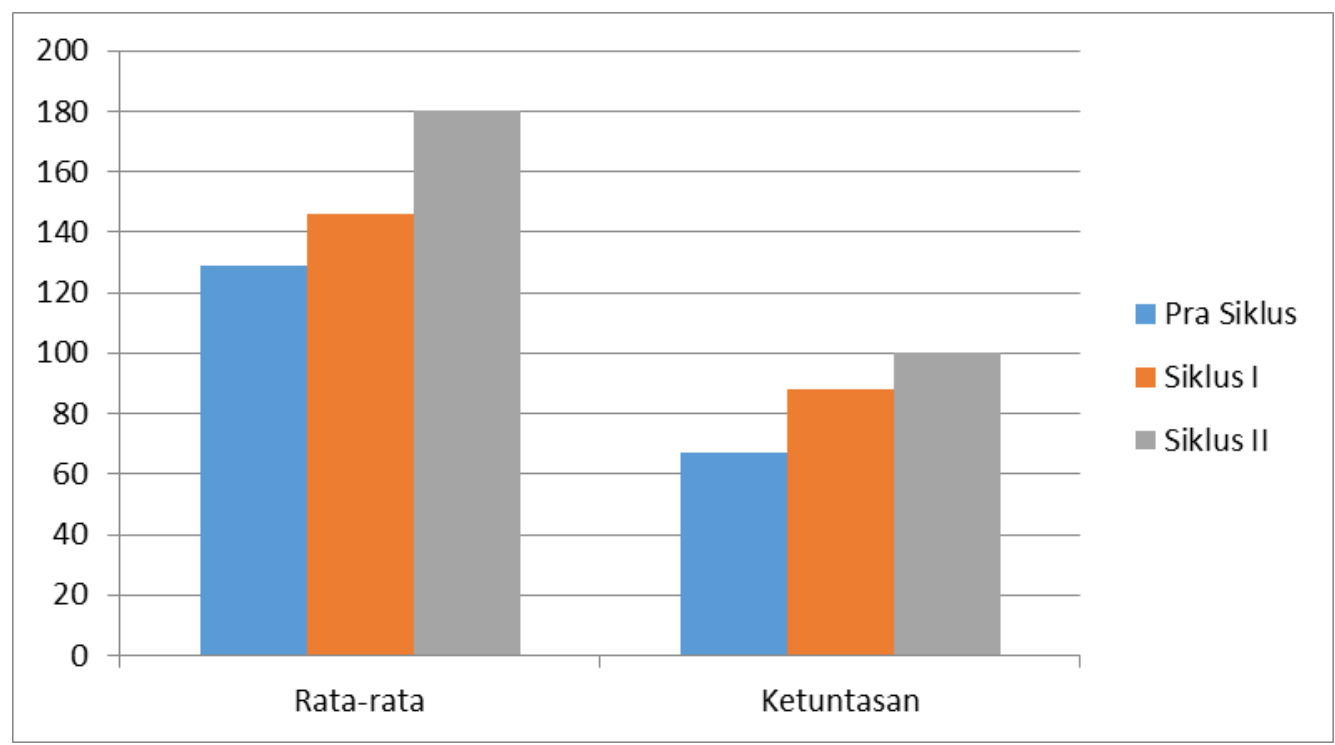

Figure 1

Improved Average and Classical Completeness

The results of this study are in line with the results of research conducted by Karmanto (2017) with the title "Supervisi Klinis: Peningkatan Kemampuan Guru dalam Mengajar di Wilayah MI Binaan Kecamatan Semin Gunungkidul Semester I Tahun 2016/2017". In his research stated that: The results of increased action in the second cycle, the average ability of teachers to teach in accordance with the standards of the process, especially in teaching performance has met the criteria for success, namely good. In the first cycle, there were $50 \%$ or half of the 6 teachers who did not meet the criteria either, 2 teachers or $33.33 \%$ with good criteria and 1 teacher or $16.67 \%$ were very good. Or the average value of cycle I 79.85 increased in cycle II to 84.30 or rose to $4.44 \%$. After being given an action in the second cycle the teacher's teaching ability became $100 \%$, one of them with very good criteria with a value of 94.22 or $16.67 \%$.

Based on the results that have been presented, it can be said that clinical supervision has a positive role in the teacher's work commitment. Cohen (Kusumaputri, 2015) defines that work commitment is a force that binds individuals to take action towards one or several organizational goals. Miller and Lee (Kusumaputri, 2015) define work commitment as a condition of organizational members who are bound by their activities and beliefs, while their function is to maintain their activities and involvement in the organization. The work commitment referred to in this study is to promise and be responsible for carrying out the work and to have a sense of dedication. Indicators of work commitment variables are: loyalty, attitude towards duties, responsibilities and self-discipline. (Oktavia \& Amar, 2012). So work commitment is the responsibility of making work and has a sense of dedication. With this clinical supervision in the form of guidance provided by supervisors can improve work comments because clinical supervision provides the opportunity for teachers to look for weaknesses and jointly solve problems, because the implementation procedure is more emphasized in finding the causes or weaknesses that occur in the teaching and learning process, and then also directly try how to correct these weaknesses or deficiencies (Ary H. Gunawan, 2002; 206 (Astuti, 2017)). The aim of clinical supervision is what is expected according to Cogan (Aziz, 2017) is to produce teachers who are professional and professionally responsible and have a high commitment to improve themselves for the help of others. Whereas Acheson and Gall (Aziz, 2017) say the purpose of clinical supervision is effective teaching by providing feedback, solving problems, helping teachers develop 
abilities and strategies, evaluating teachers, and helping teachers to behave properly as an effort to develop teachers' professionalism, with an emphasis on increasing teacher skills in teaching in a classroom.

Other findings also prove that clinical supervision can have a positive effect because because supervisors have an important role. The main role of a supervisor is to create teacher cooperation (Aziz, 2017). A supervisor is expected to carry out the following functions: 1) Diagnose and assess, 2) Plan, 3) Give motivation, 4) Give appreciation and report progress, (Aziz, 2017). In carrying out their duties the supervisor must have the following conditions: a. Confidence, having the ability to solve his own problems and develop himself. b. Having the freedom to choose and act to achieve the goals he wants. c. The ability to ask others and himself about basic assumptions and beliefs about himself. d. Commitment and will make his teacher colleagues feel important, valued and advanced. e. Having the will and ability to be able to foster close relationships regardless of feathers. $f$. The ability to listen and the desire to use the experiences of the teacher to make him try to reach the goal. g. Enthusiasm and confidence in supervision as a continuous activity process to serve the personal and professional development and development of the teacher. h. Skills in communicating, observing, and analyzing teacher behavior when teaching. i. Commitment to develop himself and eager to continue to deepen the field of supervision, Mukhtar (Aziz, 2017).

Another finding is that the success of clinical supervision is inseparable from the steps taken in the guidance process. The eight stages proposed by Cogan (Aziz, 2017) are: 1) the stage of building and strengthening the relationship of the teacher with the supervisor, 2) the planning stage with the teacher, 3) the planning stage of the observation strategy, 4) the teaching observation stage, 5) the analysis of the learning process teaching, 6) the planning stage of the meeting strategy, 7) the stage of the meeting, and 7) the stage of exploring the next meeting plan. These steps must be carried out correctly to get the planned results. Clinical supervision steps take place in a process that is in the form of a cycle consisting of three stages: the preliminary meeting stage (pre-observation), the observation stage (observation) and the feedback meeting stage (feedback / feed back)). Two of the three stages require a meeting between the teacher and supervisor, namely the preliminary meeting and feedback meeting, (Astuti, 2017). So it can be said that by carrying out clinical supervision steps will be able to achieve the goals programmed in the guidance process.

Guidance carried out by supervisors must go well or produce a good cooperative relationship, not foster teacher awkwardness because it is guided by a supervisor or principal who in this case acts as a supervisor. For the effectiveness of clinical supervision implementation, it is important to be reminded and considered by the supervisor regarding the following matters: 1) guidance (supervision) is helpful rather than intructive or relational which is implemented in the form of face-to-face relationships between supervisors and teachers 2) supervision activities are centered on what is being teacher's attention is not based on the supervisor's views or desires only 3) the object of supervision regarding the appearance of the teacher in the classroom, with the opportunity to first be held through joint assessment between supervisors and teachers 4) observation instruments developed and mutually agreed between supervisors and teachers in accordance with the agreed contract by both parties 5) data analysis and interpretation of observations carried out jointly between supervisors and teachers 6) feedback is carried out as soon as possible and objectively, 7) supervision takes place in a professional atmosphere that is healthy, intimate, and mutually open, and 8) in pr oses supervision, supervisors listen more and ask questions rather than command or give direction. (Sri Banum Muslim, 2013: 102 (Astuti, 2017)

The results of this study are supported by several research results that have been there before, including Yulia Jayanti et al. (2016) with the results of the study showing the implementation of clinical supervision carried out in three stages, namely the planning phase, the implementation phase, and the feedback stage had been going well and could increase teacher professionalism. The first step is planning. The planning carried out in this study is related to initial discussions between the principal and the teacher who will carry out clinical supervision activities. The second stage is implementation. The implementation of clinical supervision at SDIT Bumi Darun Najah focuses on the third phase of learning activities, namely feedback. Feedback activities contain activities to convey the things recorded in the assessment instrument that has been prepared. Relevance to this research is the process carried out together using the stages of planning, implementation, and feedback. Research conducted by (Utami, 2017) which states that clinical supervision improves teacher performance in the learning process, this is evident from the increase in achievement per cycle shows an increase. Research results from (Astuti, 2017) Clinical Supervision is a guidance process aimed at assisting professional development of teachers / prospective teachers, especially in teaching performance based on observation and analysis of accurate and objective data as guidelines for changing teaching 
behavior. So, it can be said that clinical supervision has a positive impact on improving teacher performance.

\section{Conclusion}

Based on research that has been done, it can be concluded that: the application of clinical supervision effectively can increase teacher work commitment at SD di Gugus 3 Kecamatan Blahbatuh Kabupaten Gianyar Semester II Academic Year 2018/2019. In the pre-cycle mean teacher work commitment is 128.74 in the medium category with the percentage of classical completeness is $67.24 \%$. In the first cycle the mean work commitment of teachers was 145.98 in the high category with the percentage of classical completeness being $87.93 \%$. Whereas, in cycle II it increased with a mean of 180.45 in the very high category with the percentage of classical completeness being $100 \%$. Suggestions that can be submitted based on research that has been done are as follows. First, the teacher is expected to be always eager to work so that the results of work produced are optimal. Second, school principals are expected to always motivate teachers in carrying out their duties, so that teacher's commitment is increased in work and teacher performance can be improved. Third, other researchers should develop this research by using more diverse variables, so that problems in education can be minimized

\section{References}

Amani, L., Dantes, N., \& Lasmawan, W. (2013). Meningkatkan Kemampuan Guru Mengelola Proses Pembelajaran Pada Guru Sd Se-Gugus. E-Journal Program Pascasarjana Universitas Pendidikan Ganesha Jurusan Pendidikan Dasar, 3.

Andani, Y., Yulianto, A., \& Murwatiningsih, M. (2017). Model Supervisi Klinis Berbasis Teknologi Informasi dan Komunikasi Untuk Menigkatkan Kinerja Guru Produktif di SMKN 1 Kota Bima. Educational Management, 6(2), 163-169. https://journal.unnes.ac.id/sju/index.php/eduman /article/view/22782

Astuti, S. (2017). Supervisi Akademik Untuk Menigkatkan Kompetensi Guru Di Sd Laboratorium Uksw. Scholaria: Jurnal Pendidikan Dan Kebudayaan, 7(1), 49. https://doi.org/10.24246/ j.scholaria.2017.v7.i1.p49-59

Aziz, A. (2017). Supervisi Pendekatan Klinik. Jurnal Studi Islam, 12(1), 2579-7131.

Depdiknas. (2005). Pembinaan Profesionalisme Tenaga Pengajar (Pengembangan Profesionalisme Guru). Direktorat Jenderal Pendidikan Dasar dan Menengah Direktorat Pendidikan Lanjutan Pertama Depdiknas.

Depdiknas. (2007). Rencana strategis Departement Pendidikan Nasional 2005 - 2009. Pusat Informasi dan Humas Departemen Pendidikan Nasional.

Euis, P. (2015). Profesionalisme Guru Dalam Mengenal Perkembangan Siswa Sebagai Subjek Belajar. Jurnal Edueksos, IV(2), 1-11.

Greenstein, L. (2012). Assessing 21st Century Skills. A guide evaluating mastery and authentic learning. Corwin a Sage Company.

Hoy, W. K., \& Horsyth, P. B. (1986). Effective Supervision,Theory into Practice. Random House, Inc.

Karmanto. (2017). Supervisi Klinis: Peningkatan Kemampuan Guru dalam Mengajar di Wilayah MI Binaan Kecamatan Semin Gunungkidul Semester I Tahun 2016/2017. Jurnal Pendidikan Madrasah, 3(3).

Kirom, A. (2017). Peran Guru Dan Peserta Didik Dalam Proses Pembelajaran Berbasis Multikultural. Al Murabbi, 3(1), 69-80.

Kusumaputri, E. S. (2015). Komitmen Pada Perubahan Organisasi. Deepublish.

Lailatussaadah, L. (2015). Upaya Peningkatan Kinerja Guru. Intelektualita, 3(1), 15-25.

Ma'mur Asmani, J. (2012). Tips Efektif Supervisi Pendidikan Sekolah. DIVA Press.

Mukhtar. (2015). Strategi kepala sekolah dalam meningkatkan kinerja guru pada SMP negeri di kecamatan masjid raya kabupaten aceh besar. Jurnal Magister Administrasi Pendidikan, 3(3), 
103-117. https://doi.org/10.24090/jk.v5i2.1931

Naro, W. (2017). Komitmen Profesi Dan Pengaruhnya Terhadap Kompetensi Profesional Guru Pada Madrasah Tsanawiyah Di Kota Makassar. Journal Fakultas Tarbiyah Dan Keguruan UIN Alauddin Makassar, 6(1), 35. https://doi.org/10.24252/ip.v6i1.3581

Novrinda, Nina, K., \& Yulidesni. (2017). Peran orangtua dalam pendidikan anak usia dini ditinjau dari latar belakang pendidikan Novrinda. Jurnal Potensia, 1(1), 61-80. https://doi.org/10.19109/ ra.v1i1.1526

Nurcholiq, M. (2017). Supervisi klinis. Evaluasi, 1(1), 1-25.

Oktavia, E., \& Amar, S. (2012). Komitmen kerja terhadap kinerja pegawai pada dinas kopperindag dan umkm kabupaten dharmasraya. http://ejournal.unp.ac.id/index.php/jrmbp/article/viewFile/ $4197 / 3312$

Sahertian, P. A. (2000). Konsep Dasar dan Teknik Supervisi Pendidikan dalam Rangka Pengembangan Sumber Daya Manusia. Rineka Cipta.

Salim, N. A. (2017). Peningkatan efektivitas pengelolaan sekolah melalui penguatan kemampuan manajerial kepala sekolah. Manajemen dan Supervisi Pendidikan, 2(1), 8-16.

Shaleh, M. (2016). Pengaruh Motivasi, Faktor Keluarga, Lingkungan Kampus Dan Aktif Berorganisasi Terhadap Prestasi Akademik. Phenomenon: Jurnal Pendidikan MIPA, 4(2), 109. https://doi.org/10.21580/phen.2014.4.2.122

Suharsini, A. (2006). Dasar-dasar Supervisi Pendidikan. PT. Rieneka Cipta.

Sumarno. (2016). Peranan guru pendidikan agama islam dalam membangun karakter peserta didik oleh: Jurnal Al Lubab, 1(1), 121-147.

Susilo, A., \& Sarkowi, S. (2018). Peran Guru Sejarah Abad 21 dalam Menghadapi Tantangan Arus Globalisasi. Historia: Jurnal Pendidik Dan Peneliti Sejarah, 2(1), 43. https://doi.org/10.17509/historia.v2i1.11206

Suwardi, I., \& Farnisa, R. (2018). Hubungan Peran Guru Dalam Proses Pembelajaran Terhadap Prestasi Belajar Siswa. Jurnal Gentala Pendidikan Dasar, 3(2), 181-202. https://doi.org/10.22437/ gentala.v3i2.6758

Utami, S. (2017). Penerapan Supervisi Klinis untuk Meningkatkan Kinerja Guru dalam Proses Belajar Mengajar Gugus IV Sanankulon. Briliant: Jurnal Riset Dan Konseptual, 2(3), 272. https://doi.org/10.28926/briliant.v2i3.70

Wasitohadi, W. (2014). Hakekat pendidikan dalam perspektif John Dewey Tinjauan Teoritis. Satya Widya, 30(1), 49. https://doi.org/10.24246/j.sw.2014.v30.i1.p49-61

Yulia Jayanti, T., Achmad, S., \& Burhanuddin. (2016). Implementasi Supervisi Klinis Dalam Meningkatkan Provesionalisme Guru. Jurnal Pendidikan: Teori, Penelitian, Dan Pengembangan, 1(11), 2332-2336.

Yulia Jayanti Tanama, Achmad Supriyanto, B. (2016). Implementasi Supervisi Klinis Dalam. Jurnal Pendidikan: Teori, Penelitian, dan Pengembangan, 1(11), 2332-2336. 